\section{The ICER Working Paper Series on Entrepreneurship and Innovation}

ISSN 2048-2426

\section{WP7}

Does entrepreneurial self-efficacy predict discontinuation of venture idea development?

by

Zarina Osmonalieva

Number of Pages: 32

INTERNATIONAL CENTRE FOR ENTREPRENEURSHIP RESEARCH

Essex Business School

University of Essex Elmer Approach

Southend-on-Sea, Essex SS1 1LW, UK

Tax: +441702 328387

www.essex.ac.uk/ebs/research/cer General correspondence to jmitra@essex.ac.uk
University of Essex

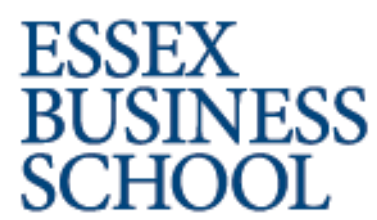

External Advisors:

Prof David Smallbone

Prof Mathew Manimala

Prof Gunnar Prause 


\title{
Does entrepreneurial self-efficacy predict discontinuation of venture idea development?*
}

\author{
February 2014 \\ Zarina Osmonalieva
}

Corresponding Author(s):

$\mathrm{PhD}$ candidate in industrial economics and organization

Mälardalens högskola, Box 883

\section{Västerås}

\section{Sweden}

E-mail: zarina.osmonalieva@mdh.se

* This paper won the best paper award for outstanding scholarship and rigour at the $12^{\text {th }}$ International Entrepreneurship Forum Conference, Vilnius, Lithuania, September, 2013 
The CER working Paper Series on Entrepreneurship and Innovation

\section{Table of Content}

$\begin{array}{lr}\text { Abstract } & 3 \\ \text { Introduction } & 4 \\ \text { Literature review } & 6 \\ \text { Methods } & 12 \\ \text { Findings } & 21 \\ \text { Discussion } & 25 \\ \text { Appendix } & 27 \\ \text { References } & 29\end{array}$ 


\section{Abstract}

Objectives: To study if entrepreneurial self-efficacy predicts discontinuation of venture idea development and how different dimensions of entrepreneurial self-efficacy related to discontinuation of venture idea development.

Theoretical Background/Previous Practice:

According to social cognitive theory, performance of individuals is predicted by their selfefficacy beliefs (Bandura, 1977). In the entrepreneurship context self-efficacy has proved to be an important variable explaining entrepreneurial intentions and performance. It has generally been studied in its relation to business start-up and business growth (Drnovsĕk, Wincent, \& Cardon, 2010). When it comes to early stages of entrepreneurship, policy makers encourage individuals to choose the career of entrepreneurs, but there are still few studies which consider the relationship of entrepreneurial self-efficacy and nascent stages of entrepreneurship (McGee et al., 2009). Opportunity discovery is considered to be one of the success factors of entrepreneurial performance, but research shows that not all discovered opportunities are exploited (Davidsson, 2008; Sarasvathy, Dew, Velamuri, \& Venkataraman, 2005; Shane \& Venkataraman, 2000). One explanation to why entrepreneurs discontinue the development of venture ideas can be low entrepreneurial selfefficacy.

\section{Approach/Methods:}

Studies about entrepreneurial self-efficacy applied general and specific measures of entrepreneurial self-efficacy. It is suggested that more task specific measurement of selfefficacy will likely have higher predictive ability (McGee, Peterson, Mueller, \& Sequeira, 2009). The explanation behind this proposition is that all-purpose operationalization cannot fully reflect the actual context (Bandura, 2006). Therefore, we employ a multidimensional construct of entrepreneurial self-efficacy which was developed by McGee et al. (2009). This construct specifically focused on the early stages of entrepreneurial process, especially entrepreneurial intentions and nascent behaviour (2009). It included measurement of entrepreneurial self-efficacy relating to the following phases of venture development: searching, planning, marshalling resources, and implementing. In the frameworks of this study we study if entrepreneurial self- efficacy predicts discontinuation of venture ideas. Because the dependent variable is a categorical variable, we applied regression analysis for categorical dependent variables.

Results/Insights:

The results show that planning and marshalling self-efficacy predict discontinuation of venture ideas. As for the direction of the relationship between planning self-efficacy and discontinuation, planning self-efficacy is positively related to the discontinuation of venture ideas, i.e., as planning self-efficacy increases the probability of discontinuing the venture 
increases. When it comes to the marshalling self-efficacy, the direction is opposite - as marshalling self-efficacy increases the probability of discontinuation decreases.

Implications:

It is difficult at early stages of entrepreneurial process to predict which venture ideas will survive, thus, such stage should be based on the idea of experimentation in entrepreneurship (Carlsson, 2005; Davidsson, 2008), where the aim is to enhance entrepreneurial potential by developing "an ability to evaluate venture ideas and environments in order to assess whether systematic and planned process applies, or a more iterative and flexible approach is called for" (Davidsson, 2008, p. 90).

Keywords: entrepreneurial self-efficacy, discontinuation of venture ideas, exit

\section{Introduction}

The entrepreneurial process involves discovery, concerned with the conception of a business idea, and exploitation of discovered opportunities, encompassing behavioural activities such as networking, business planning, etc. (Aldrich, 1999; Davidsson, 2008). Discovery of an opportunity, the first and foremost outcome of the entrepreneurial process, is conceptualized as a venture idea, defined as "a conjecture about unsatisfied needs and productive possibilities" (Davidsson, 2004). Because entrepreneurs act upon a conjecture rather than a conviction about the success of a venture idea, there are various possibilities of how the entrepreneurial process may unfold: by initiating actions and behaviours which are aimed at the realization of a venture idea and creation of a new business with regular sales or by termination of these activities (Davidsson, 2008). Therefore, despite that discovery of an entrepreneurial opportunity is the indicator of success, not all discovered opportunities will be exploited (Davidsson, 2008; Sarasvathy, et al., 2005; Shane \& Venkataraman, 2000).

Why are some venture ideas exploited, while others are terminated? Discovery of venture ideas and willingness to exploit them can be explained by a number of factors related to the intersection of an individual and an opportunity, according to Shane and Venkataraman (2000). This nexus is especially relevant during nascent stages of entrepreneurship when the firm is not yet existent.

As for opportunities, researchers identify the higher expected value (Shane \& Venkataraman, 2000) and innovativeness of opportunities (Amason, Shrader, \& Tompson, 2006; Isaksen, 2006; Samuelsson, 2004) as particular features of opportunities which can have impact on the exploitation. Scholars propose that variation in opportunities can in fact have more influence on the continuation of the exploitation effort than characteristics of individuals, but this topic has not been widely researched in the entrepreneurship field (Ireland \& Webb, 2007; Samuelsson, 2004; Shane \& Venkataraman, 2000). Variation in opportunities can be measured in various ways. Besides innovativeness and higher 
expected value, tangibility of a new offering can be a variable that measures variation. It is admitted that the development of services might vary from the development of products due to structural differences stemming from, among other factors, low relevance of intellectual property rights in contract to cases with physical products (Ordanini \& Parasuraman, 2011). Devece et al. (2011) assume that individual entrepreneurs are less likely to succeed in manufacturing industries due to the difficulties in attaining economies of scale stemming from working with large volumes of production with the exception of low-tech patented ventures. They suggest that flexibility and, for instance, lack of need in storages and thus low levels of investments, service industries could be rather attractive for individual entrepreneurs. Quite the contrary is demonstrated by results of van Gelderen's study about the startup success and risk (2006). Those entrepreneurs who started their businesses in manufacturing were more likely to succeed in startup process in comparison with those who started in other sectors: business and consumer services and trade. There is a lack of empirical studies about the differences of products and services in entrepreneurship research mainly due to the fact that service innovation and entrepreneurship in service industries are rather new areas of research (Devece, et al., 2011; Ordanini \& Parasuraman, 2011).

On the individual level of analysis a multitude of factors can affect the continuation of the entrepreneurial endeavour. Among them are socio-demoFigureic variables such as age, parenting, membership in minorities, human and social capital, education and work experience, job satisfaction and salary at previous workplace (Dobrev \& Barnett, 2005), and other variables as availability of initial financial capital, perception of risk, optimism, tolerance to ambiguity (Shane \& Venkataraman, 2000), self-efficacy (Chen, Greene, \& Crick, 1998; Krueger, 2000) and outsider assistance (Chrisman \& McMullan, 2004). As it is individuals who exercise control over their lives and discover and exploit opportunities, it is important to investigate what type of skills and abilities they need for completing different tasks. According to the social cognitive theory, performance of individuals is predicted by their self-efficacy beliefs (Bandura, 1977). It refers to an individual's assessment of his or her "capabilities to mobilize the motivation, cognitive resources, and courses of action needed to exercise control over events in their lives" (Bandura, 1997). The concept of self-efficacy was borrowed from social cognitive theory and has become accustomed in entrepreneurship research. The main assumption of social cognitive theory is that individuals act proactively, not reactively. Human agents operate within an interdependent causal structure involving personal factors, behavior and environment and thus their selves are socially constituted, but as they can exercise self-influence, they are partial contributors of what they become and do (p. 6, Bandura, 1997). According to Bandura, specific selfefficacy is a better predictor of performance, in the case of entrepreneurs it is multidimensional self-efficacy, which conveys beliefs in different tasks of an entrepreneur, as for instance, marshalling resources or planning. Entrepreneurship researchers have designed and tested several multi-dimensional constructs of entrepreneurial self-efficacy, but only McGee et al. standardized it on the sample of nascent entrepreneurs (2009) making it a relevant construct for studying sets of abilities necessary during early stages of the entrepreneurial process. 
Because service development and product development processes differ, nascent entrepreneurs who have discovered venture ideas based on either services or products might need different sets of entrepreneurial self-efficacy during the nascent stage of entrepreneurship. This in turn might influence the outcome of the discovery process.

The research question raised in this article is:

Which dimensions entrepreneurial self-efficacy predict discontinuation of venture ideas? Is there a difference in prediction of discontinuation of venture ideas based on products and venture ideas based on services?

\section{Literature review}

This chapter contains the review of literature on new service development and entrepreneurial self-efficacy.

New service development

According to the literature on new service development, the development of new services differs from the development of new products. It was shown that consumers' participation in the design of a new service is higher than in new product development process (Song, L., Song, M., Benedetto, A., 2009). It is not surprising, because services are intangible and service companies need to know needs and wants of their customers (Edvardsson \& Olsson, 1996). Not only service companies need to get clear information from customers about future services and customers' expectations, but customers become central to the new service development process by being actively involved during the whole process from service design to service encounter (Edvardsson \& Olsson, 1996). This is in contrast to the new product development process, which happens in one time and one place and without customers' participation. From the firm's perspective, in order to design new services and maintain service delivery, all departments need to work in unison in order to create a good basis for service delivery. Besides this, employees of the company who are involved in encounters with customers need to be motivated to do their work, as service quality research showed that customers had rated services high quality, when employees during encounters demonstrated commitment to solve customers' problems and knowledge to be able to do this task (Edvardsson \& Olsson, 1996).

Perceived entrepreneurial self-efficacy

Self-efficacy in entrepreneurship research

The concept of entrepreneurial self-efficacy can help investigate the sets of abilities or competences needed for successful implementation of entrepreneurial tasks. It was borrowed from the social cognitive theory and has become accustomed in entrepreneurship research. According to social cognitive theory, performance of individuals is predicted by their self-efficacy beliefs (Bandura, 1977). It refers to an individual's assessment of his or 
her "capabilities to mobilize the motivation, cognitive resources, and courses of action needed to exercise control over events in their lives" (Bandura, 1997). The main assumption of social cognitive theory is that individuals act proactively, not reactively. Human agents operate within an interdependent causal structure involving personal factors, behavior and environment and thus their selves are socially constituted, but as they can exercise self-influence, they are partial contributors of what they become and do (p. 6, Bandura, 1997).

For actions towards set goals individuals need to have beliefs about their power to produce results and without such beliefs individuals will not attempt actions. But according to the social learning theory, even intentional actions do not always produce desirable results as individuals are a part of the surrounding environment and lack control over environmental factors:

"Many actions are performed in the belief that they will bring about a desired outcome, but they actually produce outcomes that were neither intended nor wanted"

(p. 3, Bandura, 1997).

Beliefs about capabilities to attain goals refer to the general self-efficacy, which generally is defined as the overall assessment of individuals' belief in their capabilities (Bandura, 1977). As research shows, self-efficacy can be developed in individuals by mastery or successful experiences, vicarious experiences which create personal beliefs through comparison with others, verbal persuasion made by significant others and good affective and physiological states which give the perception of well-being and competence (Bandura, 1997). Scholars distinguish general and specific self-efficacy, where general self-efficacy reflects the overall evaluation of one's capabilities, while specific self-efficacy is related to a specific activity.

General self-efficacy versus entrepreneurial self-efficacy

Self-efficacy has proved to be an important variable explaining entrepreneurial intentions and performance. It has generally been studied in its relation to business startup and business growth (Drnovsĕk, et al., 2010). Such studies included measures of both general and specific, i.e., entrepreneurial self-efficacy. For instance, general self-efficacy was found to be a predictor of intentions to become an entrepreneur and a feature that distinguishes innovators who commercialize their innovations from those who did not (Drnovsěk, et al., 2010; Klofsten, 2005).

There is a debate between scholars in the entrepreneurship field about which measures of self- efficacy are most applicable in entrepreneurship studies. Those who advocate usage of general self-efficacy measures suggest that it is sufficient to use this measure as it is a stable trait-like competence belief (Chen, Gully, \& Eden, 2004) and because entrepreneurs need diverse set of roles and skills it would be difficult to identify specific competences associated with entrepreneurship activities, i.e., related to entrepreneurial selfefficacy (McGee, et al., 2009). Others refer to the argument that more task specific 
measurement of self-efficacy will likely have higher predictive ability (McGee, et al., 2009). The explanation behind this proposition is that all- purpose operationalization cannot fully reflect the actual context (Bandura, 2006).

Entrepreneurial self-efficacy refers to the specific self-efficacy and is the belief in one's ability to succeed in an entrepreneurial endeavour, which was also found to be an important measure of perseverance in entrepreneurial endeavour (Mueller \& McGee, 2007). McGee et al suggest that entrepreneurial self-efficacy is a construct that measures a "person's belief in their ability to successfully launch an entrepreneurial venture" and is believed to play an important role in determining an individual's choice, level of effort and perseverance (2009). Boyd and Vozikis (1994) define entrepreneurial self-efficacy as "the strength of an individual's belief that he or she is capable of successfully performing the roles and tasks of an entrepreneur" (in Chen et al., 1998).

Entrepreneurial self-efficacy is considered an important construct, but there have been challenges with its conceptualization and measurement (Drnovsěk, et al., 2010). In some studies a uni-dimensional measure of entrepreneurial self-efficacy was applied. For instance, respondents were asked a single question about the overall evaluation of entrepreneurial self-efficacy as a measure of entrepreneurial self-efficacy (McGee, et al., 2009). Other scholars advocate the application of multi-dimensional construct of entrepreneurial self-efficacy as studies have shown that specific types of self-efficacy have different effects on intentions and actual performance (Chen, et al., 1998; Drnovsĕk, et al., 2010; McGee, et al., 2009). In addition, Bandura recommends focusing on a specific context and activity domain when carrying out studies about self-efficacy (Bandura, 1977, 1997).

\section{Multi-dimensional construct of entrepreneurial self-efficacy}

The earliest multi-dimensional construct entrepreneurial self-efficacy was developed by Chen et al. (1998). They carried out one study with 130 university students and another study with 175 entrepreneurs and managers, where they used scales based on the literature review about entrepreneurs' tasks and roles referring to the following areas: marketing, innovation, management, risk-taking and financial control.

Scholars are in agreement when it comes to the construction of the entrepreneurial selfefficacy measure. They suggest that the actual tasks of entrepreneurs in a chronological order should be taken as the base (Drnovsĕk, et al., 2010; McGee, et al., 2009; Mueller \& Conway Dato-On, 2008). For instance, Mueller and Conway Dato-On (2008) identify four different steps and respective tasks of entrepreneurs. The first step is the development of a unique idea or identification of a special opportunity. The second step is activities aiming at converting the idea into a business plan. The third and fourth stages are devoted to assembling resources and management practice.

Drnovsěk et al. (2010) suggest that when designing measures of entrepreneurial selfefficacy the goals of entrepreneurs need to be taken into consideration, for instance, to start 
a business or to grow a business. They suggest that different stages of the entrepreneurial process require different sets of competences, thus, different constructs of self-efficacy should be applied in studies. As per the start-up phase, they propose a conceptualization of entrepreneurial self-efficacy based on the activities during the early stages: entrepreneurial intent, opportunity search, decision to exploit, and opportunity exploitation and offer propositions for future research. Their study does not contain operationalization and empirical test of such measure, but they make an important point about the way entrepreneurial self-efficacy should be conceptualized. Drnovsěk et al. suggest that researchers have to pay attention to the entrepreneurial self-efficacy related to the confidence in executing a range of tasks and the entrepreneurial self-efficacy related to the ability to master necessary competences to effectively deal with the environment in order to complete the set tasks (Drnovsěk, et al., 2010). Both conceptualizations are important and should be distinguishable because they measure two different types of self-efficacy, according to the authors.

McGee et al. have developed a multi-dimensional construct of entrepreneurial selfefficacy specifically focused on the early stages of entrepreneurial process, especially entrepreneurial intentions and nascent behavior (2009). Their conceptualization of entrepreneurial self-efficacy is based on individuals' belief in their capability to accomplish a set of tasks (Bandura, 1977). McGee et al. tested their construct on the sample of nascent entrepreneurs in contrast to the earlier studies where constructs of entrepreneurial self-efficacy were applied to the samples of students or managers. It included measurement of entrepreneurial self-efficacy relating to the following phases of venture development: searching, planning, marshalling resources, and implementing.

The searching phase encompasses the development of a unique idea or identification of an opportunity. During planning phase the entrepreneur transforms the idea into a business plan. Marshalling phase is associated with assembling resources in order to bring the venture into existence. The last phase involves the tasks related to growing and sustaining the business past its infancy (McGee, et al., 2009). Using factor analysis McGee et al. identified five sub-constructs of entrepreneurial self-efficacy associated with four stages of the venture development process. The last dimension, implementing, was found to be consisting of two sub-dimensions: implementing people and implementing finances.

Below we present the review of research on the effect of different aspects of entrepreneurial self-efficacy on different indicators of performance (see Appendix 2). Research has shown that there is a significant and positive associated between the total entrepreneurial self-efficacy and the intention to start a business (Chen, et al., 1998), for instance, but specific domains of entrepreneurial self-efficacy can be more informative in explaining different indicators of performance. The review is divided into searching, planning, marshalling, implementing people, and implementing finances, which comprise five domains of entrepreneurial self-efficacy, according to McGee et al. (2009). As the construct developed by McGee et al (2009) is rather new and have not been applied to 
empirical studies yet, we will include constructs different from entrepreneurial self-efficacy, but pertaining knowledge, competence or skills necessary during the discovery process.

Searching self-efficacy

The first phase refers to the ability to search for entrepreneurial opportunities. This ability is an important feature of an entrepreneur as it reflects his or her creative talents and ability to innovate (McGee, et al., 2009). In fact this ability signals about sensitivity to entrepreneurial opportunities which is shaped by background, experience, amount and type of information about the opportunity (Ardichvili, Cardozo, \& Ray, 2003). Several studies were conducted about search behavior of entrepreneurs and propose that active searching strategies can lead to the discovery of venture ideas with greater wealthcreating potential (Fiet, 2007). Similarly, in Puhakka's study competitive scanning and proactive searching referring to searching activities were found to be significantly affecting newness value of products (2007).

Studies about entrepreneurs and managers showed that entrepreneurs were particularly skilful in recognizing and exploiting opportunities in contrast to managers (Chen, et al., 1998). For instance, Chen et al. discovered that in contrast to managers, entrepreneurs who founded businesses had higher self-efficacy as innovators, whose role was defined in terms of abilities to recognize opportunities such as new products, markets and methods of production.

Although entrepreneurs in this study have already discovered opportunities and have exercised their searching self-efficacy, it can still be relevant when it comes to the design of new products or services and knowledge about customers' preferences. So we propose that:

Hypothesis 1: Lower searching self-efficacy predicts discontinuation of venture ideas.

Planning self-efficacy

The second domain is the ability to plan. Planning and business planning in particular have been of interest among entrepreneurship researchers (Castrogiovanni, 1996; Delmar \& Shane, 2003). Castogiovanni (1996, p. 803), for instance, when discussing planning prior to starting business, defines planning as "the process by which the entrepreneur, in exploiting an opportunity, creates a vision of the future and develops the necessary objectives, resources, and procedures to achieve that vision". McGee et al. define the planning phase as activities which help entrepreneurs convert the idea into a business plan which does not have to be necessarily formal, but rather an evaluation of the feasibility of the future business in terms of the operational costs, product manufacturing, market size, etc (2009).

Preparing a business plan is considered to be an important activity as it bridges entrepreneurs to further activities (Cooper \& Mehta, 2006). There are contrasting opinions as well, arguing that planning is not important in some contexts and that rigid business plans, on the contrary, might hinder advancement in the entrepreneurial process 
(Castrogiovanni, 1996, p. 802). Delmar and Shane (2003) attempted to oppose the view that planning hinders the development of ventures during early stages of entrepreneurship and actually found that business planning facilitated product development and ventureorganizing activities in new ventures. They suggest that planning helps entrepreneurs because it, first of all, enables them finding missing information without rushing into serious commitments, it provides instruments for managing the supply and demand of necessary resources, and finally it enables entrepreneurs achieving broader goals in a well-timed manner. In line with this study, we also propose that planning can actually help entrepreneurs create a strategy about the exploitation of their venture ideas and those entrepreneurs who lack planning self-efficacy will tend to discontinue their venture ideas.

\section{Hypothesis 2: Lower planning self-efficacy predicts discontinuation of venture ideas.}

Marshalling and Implementing people self-efficacy

If planning abilities refer to the conceptual development of venture ideas, marshalling refers to activities aimed at gathering resources necessary for the exploitation of opportunities (McGee, et al., 2009). This is an important ability for entrepreneurs because at early stages of entrepreneurship they need to convince investors, potential partners and customers that the future products or services are innovative and worthy of exploitation. Findings suggest that networking is the key for the success of new ventures because it helps entrepreneurs gain resources from the external environment: venture capitalists, counsellors, bankers, etc (Bird, 1988). Marshalling self- efficacy seems to be highly important during the nascent stages of entrepreneurship because if entrepreneurs don't master it, they will fail in communicating their surroundings in the value of their venture ideas. Similarly, it is important that entrepreneurs have high self-efficacy in guiding employees, they need to improve their ability to verbally share their vision with others, and to lead people in order to sustain business (Bird, 1988; McGee, et al., 2009).

Hypothesis 3: Lower marshalling self-efficacy predicts discontinuation of venture ideas. Hypothesis 4: Lower self-efficacy in guiding employees predicts discontinuation of venture ideas.

Implementing finances self-efficacy

This dimension of entrepreneurial self-efficacy has been named differently in entrepreneurship studies. Chen et al (1998) call it financial control, which is comprised of abilities to perform financial analysis, develop financial system and internal controls as well as control costs. Isaksen (2006) uses a similar construct, economic management, which refers to the ability to manage cash flows and expenses and control business costs. In Isaksen's study it was shown that economic management is positively and significantly associated with early business performance in terms of sales, investment capital and employment.

Hypothesis 5: Lower self-efficacy in implementing finances predicts discontinuation of venture ideas. 


\section{Methods}

$1 \quad$ Data collection method

As all other types of research, survey research has its weak and strong points. One commonly known disadvantage of survey studies is that what is measured in studies is not attitudes, intentions, goals, in order words, real-world behaviors, but "paper-and-pencil behavior" (Davidsson, 2008). However, survey research enables researchers to conduct studies at a relatively low cost and creates a more objective investigation in contrast to case studies as well as enables analysis of complex relationships of a large number of variables (Davidsson, 2008, p. 166). In addition, surveys can help enhance knowledge by showing the trends and differences among sub-groups within a sample. Having said that, we admit that there is a growing demand in longitudinal design studies in entrepreneurship research, especially when measuring performance of individual entrepreneurs, as such design captures dynamics and processes in the best way (Davidsson, 2008; Delmar, Davidsson, \& Gartner, 2003; Wiklund, 1998).

\section{The questionnaire development process}

The first draft of the questionnaire contained single item variables, as well as summated scales ${ }^{1}$ or constructs consisting of several indicators. In order to refine the questionnaire a pilot study was conducted in autumn 2010. The aim of the pilot study was to develop the final questionnaire. The pilot study consisted of two parts: interviews and test study. Five entrepreneurs from Idelab at Mälardalen University ${ }^{2}$ were asked to fill in questionnaires and give their feedback. This group of entrepreneurs was chosen because of ease of information access as well as their similarity to the research group - entrepreneurs who were in the process of developing their venture ideas with the help of counsellors from Idelab. Respondents gave feedback on question formulation, time to fill in and the length of the questionnaire.

As for the test study, its population was a subsample of 200 individuals drawn from the sample of 4000 individuals who had addressed a support agency in the city of Stockholm since 2007 to 2010. Overall, 17 participants took part in the web-based survey, which is correspondent to a $8.5 \%$ response rate. The pilot study showed that the questionnaire was lengthy and that respondents did not have time to answer all questions. This resulted in a large amount of missing answers, but also direct contact and discussions with some respondents. As a result of the pilot study the number of questions was reduced and questions simplified.

\section{Participants}

The empirical setting for this study is the organization Innova ${ }^{3}$, one of the actors in public advisory services market in Stockholm area. 
Innova was founded in 1993 by a group of inventors and has been financed by the City of Stockholm. As inventors found it difficult to foresee which venture would be successful, they developed a practice of helping as many clients as possible to develop good inventions and business ideas. Due to this Innova came to apply a makethe-winner selection strategy to their clients, which implies that the majority of individuals addressing them will take part in their program. The general assumption about clients and their ideas at Innova is that "there are no bad ideas, just weak ideas which need modification". In some cases individuals have several ideas, but they have to choose one venture idea to develop in cooperation with advisors from Innova.

However, having developed one idea they are welcome back with a new one and Innova has a group of returning entrepreneurs among their clients.

One of the main features when it comes to Innova's services is their network, which contains actors from different industries. Nowadays there are around 300 contacts of potential clients, suppliers and experts in this network whose services are purchased by Innova for their clients. In the past seminars, workshops and meetings of customers and service providers used to take place, but at the time of data collection this service was discontinued.

Innova provides seed finances, which are directed to patenting, development of venture idea, juridical matters, development of technology, prototypes, and design. There have been changes in Innova's services over the years. This has partly been influenced by the changes in the content of venture ideas. If previously, venture ideas were related to patentable inventions, nowadays the clientele in Innova has become diverse, including everything from entrepreneurs developing daily use products, for instance, parenting products, to complex high technology products. Also the economic climate has affected the composition of clients. Thus, when the IT-boom of the 1990's crashed Innova got many clients from downsizing and bankrupt IT-companies in the Stockholm area.

1 Summated scales is a method of measuring "the same concept into a single variable to increase the reliability of the measurement through multivariate measurement" (Hair, Black, Babin, Anderson, \& Tatham, 2006, p. 2).

2 University Incubator that helps students, personnel and researchers at Mälardalens Högskola http://www.mdh.se/idelab/

3 The real name of the organization is concealed 
The population of the study

As mentioned previously, little research about early stage entrepreneurship has been conducted due to the lack of access to empirical data (Davidsson, 2004). In our case Innova has given access to the population of four thousand individual entrepreneurs who have received business advice and seed financing for development of their venture ideas from 2007 to 2011. All participants who used services under this period once or more times were the population of the study. They were contacted by employees of Innova by email and were asked to take part in the study.

The sample: data collection and response rate

The data collection method is a web-based survey. Usage of web-based survey is rather common nowadays as access to internet has become ubiquitous. Web-based survey enabled to conduct an anonymous study as entrepreneurs are sensitive to disclosure of their venture ideas and financial issues. The platform chosen for the survey was www.netigate.se, which allows transferring collected data into different formats.

In 2007 Innova started systematically to ask their client on which email address they could be reached. Since this practice was adopted Innova had had 4000 clients who had participated at least in one meeting with advisors from Innova.

Data was collected from the 4th of February to the 28th of July 2011. We sent out 4000 emails to individuals having participated at least in one meeting with advisors from Innova. Respondents were asked to click on a link and fill in the web-based questionnaire. Around $10 \%$ of the emails were returned because users did not use those addresses any longer. On the 20th of April and on the 9th of June emails with reminders to fill in the questionnaires were sent to respondents. 379 respondents access the web-based questionnaire from the 4th of February to the 19th of April 2011. On the 20th of April emails with reminders about the survey were sent to all 4000 respondents, which helped to receive 62 additional responses and the number of respondents having accessed the questionnaire reached 441 individuals by the 8th of June 2011. After the second reminder which was sent on the 9th of June 2011 and until the 28th of July 2011 new 252 respondents filled in the questionnaire. Overall, by the 28th of July 693 respondents accessed the web-questionnaire published on the website of www.netigate.se.

Table 1. The study's sample

The number of respondents having accessed the questionnaire from the $4^{\text {th }}$ of February to

\begin{tabular}{|l|l|l|}
\hline & Number & $\%$ \\
\hline By the $19^{\text {th }}$ of April & 379 & 54,7 \\
\hline After the first reminder & 62 & 9.0 \\
\hline After the second reminder & 252 & 36.3 \\
\hline
\end{tabular}


Of 4000 respondents who were sent emails with the request to fill in web-based questionnaires, 693 individuals accessed the platform. 46 of them (6.6\%) did not answer questions. 101 respondents of $693(14.6 \%)$ filled in $10 \%$ or less of the questionnaires. Their answers were deleted because they did not contain enough information for analysis. Deletion of answers of respondents who did not attempt filling the questionnaire and of those who provided incomplete answers led to the sample total to 546 . Then 137 cases $(19.8 \%)$ were not included into the analysis as they did not contain answers to important independent variables involved in analysis (gender $(n=414)$ and age $(n=409)$.

Thus, 284 cases were excluded from analysis and 409 respondents comprised the overall sample of the study. However, these 409 cases contained some missing values as well. Statistical methods of analysis used in this study require listwise deletion, thus when applying them to research models the samples for four research models varied.

Table 2. The sample developmental process

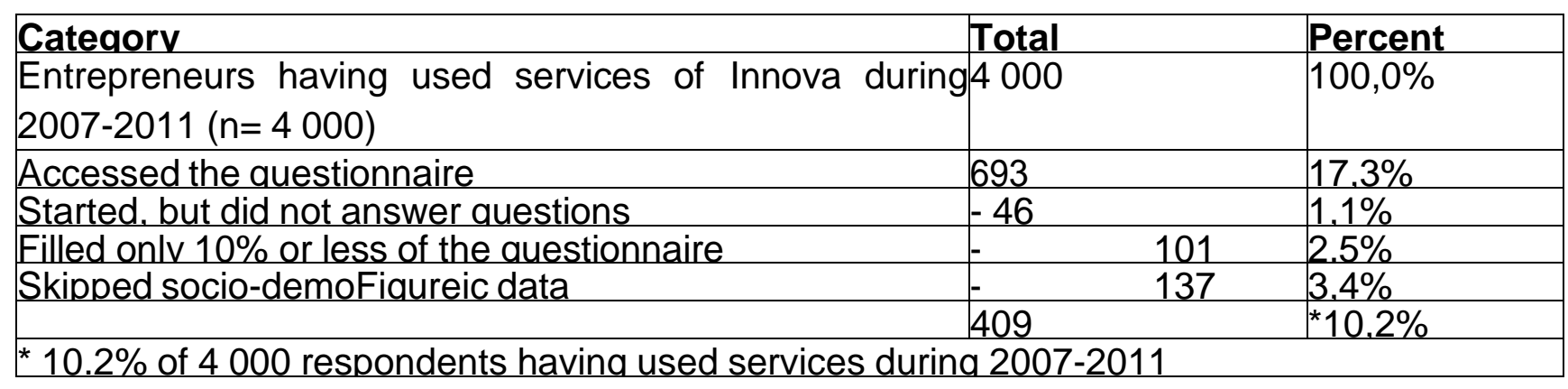

Dependent variable

Van Gelderen (2006) conducted a longitudinal study where the dependent variable was the status of the venture measured four times after the initial screening. Respondents were proposed four alternatives to the question question "How would you classify your firm?": 1) operational and running, 2) are you still setting up the business, 3) is the start-up effort temporarily inactive, 4) have you completely abandoned your start-up effort.

The above alternatives were adopted from van Gelderen's study and were transformed to imply the status of development of venture ideas. Outcomes were measured by the question: "Have you commercialized your product or service?" The alternatives offered to respondents are presented in Table 3. 
Table 3. Outcomes of the discovery process (1)

\begin{tabular}{|l|l|l|}
\cline { 3 - 4 } & Frea. & Percent \\
\hline 1. $\quad$ Yes, in the company that I ran before I came to Innova & & \\
\hline 2. Yes, I started a company for commercializing my venture idea & & \\
\hline $\begin{array}{l}\text { 3. No, but I sold it to another company which commercialized } \\
\text { without my participation }\end{array}$ & 0,5 \\
\hline $4 \quad \quad$ No, I abandoned the venture idea & 57 & 13,9 \\
\hline $5 . \quad$ No, I delaved implementation of the venture idea & 64 & 15,7 \\
\hline $6 . \quad$ No, but I am still working on development of this venture idea & & \\
\hline Total & 409 & 100,0 \\
\hline
\end{tabular}

There outcomes were later collapsed into two categories: 1) exploitation (alternatives 1, 2, 3, 6) and 2) discontinuation (alternatives 4 and 5). After this measure, the category of entrepreneurs who discontinued their venture ideas was 121 or $30 \%$ of the whole sample $(\mathrm{N}=409)$.

Table 4. Outcomes of the discovery process (2)

\begin{tabular}{|l|l|l|}
\hline Outcome & Frequency & $\%$ \\
\hline Discontinuation & 121 & $30 \%$ \\
\hline Exploitation & 288 & $70 \%$ \\
\hline Total & 409 & $100 \%$ \\
\hline
\end{tabular}

Independent variable

\section{Perceived entrepreneurial self-efficacy}

Perceived entrepreneurial self-efficacy measure is adopted from the study of McGee et al (2009). They have developed a standardized measure of entrepreneurial self-efficacy based on the sample of nascent entrepreneurs, i.e., individuals who engage in activities that meant to result in feasible business startup and baseline group, group of people from the general population. Initially there were 75 items developed by the authors, which were limited to 19 items after conducting factor analysis. The scale is comprised of five subscales: searching, planning, marshalling, implementing-people, implementing-financial and attitude toward venturing. The advantage of these scales is that McGee et al. (2009) formulated the statements about perceived entrepreneurial self-efficacy in terms of judgments as recommended by Bandura (2006). According to Bandura, as self-efficacy reflects capabilities of individuals, they should be formulated in terms of judgments of capability rather than statements of intention. Similarly, when it comes to entrepreneurial self-efficacy in particular, Drnovsěk et al. also suggest that it can be either formulated in terms of task or outcomes, where the first formulation informs about task-specific self- 
confidence rather than a belief in abilities to master necessary competences (2010). Therefore, respondents were asked to judge their capabilities in entrepreneurial tasks.

Control variables

\section{Product versus service}

The tangibility of future offerings was measured on the scale from 1 to 7 , where 1 denoted product and 7 service. The mean values were around 2.3 indicating that the level of tangibility in entrepreneurs' future offerings is rather high, although there were 34 entrepreneurs who want to provide only service. However, this variable was transformed into a dichotomous variable ( $1=$ product, $0=$ service), where alternatives from 2 to 7 referred to service and $1-$ to product.

Figure 1. Product and service $(\mathrm{N}=407)$

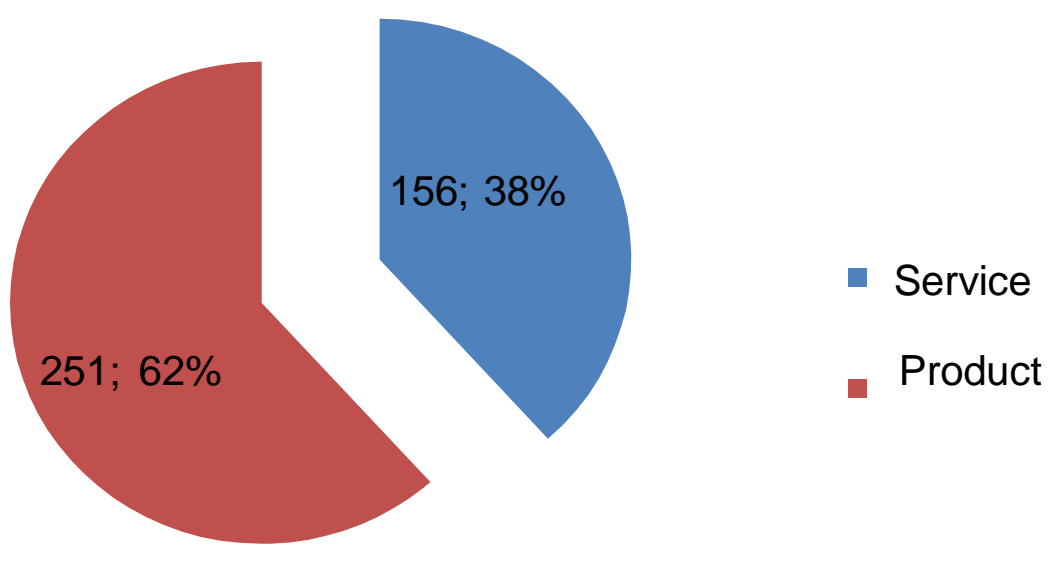




\section{Gender}

Gender is a commonly used control variable in entrepreneurship studies (Davidsson \& Honig, 2003; Isaksen, 2006; Rotefoss \& Kolvereid, 2005; Ucbasaran, et al., 2008). The reason behind including gender into quantitative studies as a control variable is because there have been found significant differences between men and women in terms of their involvement and progress in entrepreneurship. The explanation behind differences has been that women usually have lower human capital due to temporary withdrawal from labor force to raise children and due to lack of experience which allows them to mobilize resources (Delmar \& Davidsson, 2000; Ucbasaran, et al., 2009).

When it comes to entrepreneurship in Sweden, underrepresentation of women, according to Delmar and Davidsson (2000), might have its grounds in the fact that women have traditionally been employed by large, non-profit organizations in public sector where private initiatives are not encouraged. Despite some improvements in policies directed towards involvement of women in entrepreneurship in Sweden, the percentage of women in contrast to men who undertake entrepreneurial endeavor was still low as of 1998 - 27 percent versus 73 percent (Delmar \& Davidsson, 2000). In our sample the proportion of women is larger $-39 \%$ versus $61 \%$ of male entrepreneurs (see Figure ).

Figure 2. Gender of respondents $(\mathrm{N}=409)$

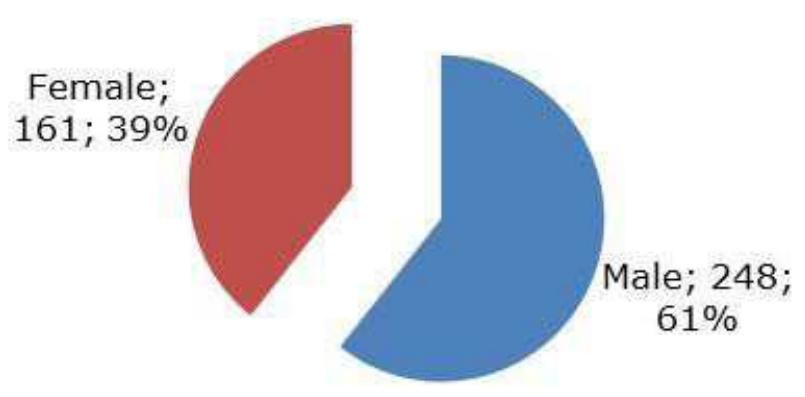

The length of contact with counsellors

The participants of this study were sampled at a support agency which they addressed at different points of time, from 2007 to 2011. The findings showed that the majority of entrepreneurs have been in contact with counsellors during the last twelve months (76\%). 15\% of respondents have been in contact with the agency during the last 24 months and only $9 \%$ of respondents indicated that they had received some sort of support from Innova. These numbers indicate that entrepreneurs who received assistance between 2007-2010 are underrepresented in the sample. 
Figure 3. Length of contact $(\mathrm{N}=379)$

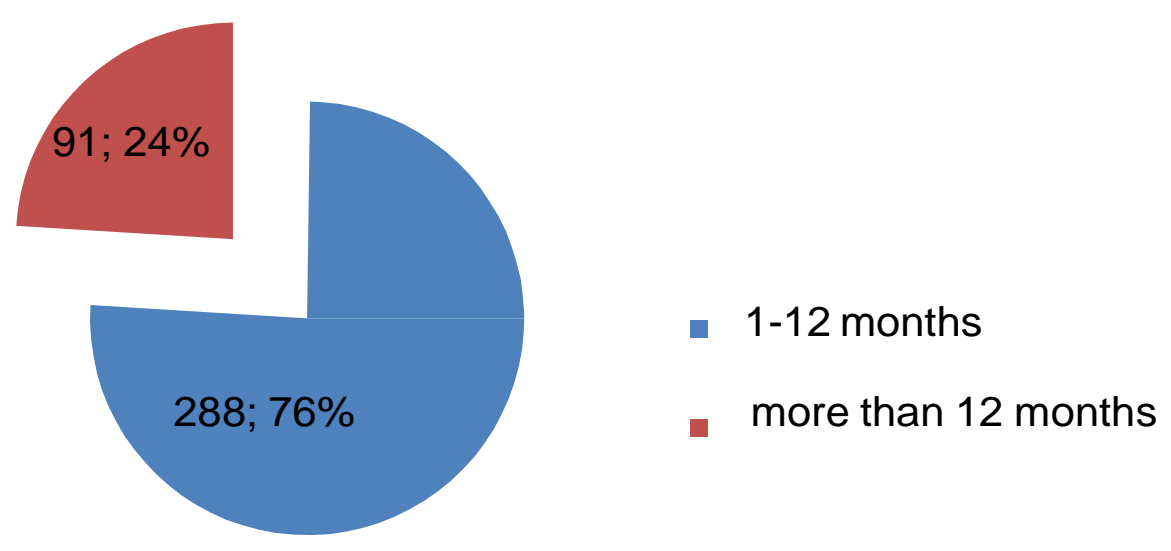

Regression-type statistical methods

Usage of categorical dependent variables in entrepreneurship research is rather common. Studies have investigated cases when two or more categories corresponded to various outcomes of the entrepreneurial process, such as discovered an opportunity versus not discovered an opportunity, the success of exploitation, formation of a startup, etc. (Chrisman \& McMullan, 2004; Davidsson \& Honig, 2003; Dimov, 2010; Hechavarria, Renko, \& Matthews, 2011; Rotefoss \& Kolvereid, 2005; van Gelderen, et al., 2006). This study aims at investigating factors predicting the outcomes of the discovery process. However, as the dependent variable in this study is categorical, linear regression models are inapplicable. The following sections describe models used for cases when dependent variables are categorical. In order to study how different factors predict these outcomes, we employ regression analysis. Regression-type statistical models can be used for different research goals. Their aims can vary between causation, prediction, and description (Powers \& Xie, 2008).

Regression analysis with categorical dependent variables

Before conducting regression analysis, it is essential to consider the type of measurement of variables to be used. In the case of independent variables, whether they are continuous or categorical does not play a major role in regression models, however, when dependent variables are categorical, application of linear regression models which are generally used for continuous dependent variables, becomes problematic (Powers \& Xie, 2008). In such situations special statistical methods, regression models for categorical dependent variables are needed.

Models for binary outcomes and assumptions

When the dependent variable is binary, there is a positive outcome of some particular event, which is coded as 1 and there is a negative outcome coded as 0 . Regression 
models for binary outcomes enables researchers investigate how independent variables influence the probability of the positive outcome (Long \& Freese, 2006, p. 131). There are two binary regression models, logit and probit, which create similar results, but operate under different assumptions. In probit models there is an assumption that the dependent variable follows a normal distribution, while in logit models the distribution of the dependent variable is logistic. Logit models have been used extensively in social sciences due the simplicity of interpretation, therefore, it is preferred over probit in the frameworks of this study as well.

As regression models for categorical dependent variables are non-linear they require usage of software packages which are able to run the analysis complying with different sets of assumptions. The analysis of regressions was conducted with the help of STATA software. Binary logit model is based on maximum likelihood estimates, which are "the values of the parameters that have the greatest likelihood of generating the observed sample of data if the assumptions of the model are true" (Long \& Freese, 2006, p. 76). The sample size for binary logit and probit models should be not less 100 and preferably over 500 cases, according to Long and Freese (2006).

Interpretation in logit models

Because logit models are nonlinear, the relationship between variables and the outcomes cannot be fully described simply because estimated parameters do not convey useful information about their relationship (Long \& Freese, 2006; Medina, 2011). In order to interpret data we need to resort to different methods of interpretation, which will be described below. It is necessary to keep in mind that no single approach is satisfactory and choosing more than one methods might help find the method that can describe the relationship of data in the best possible way.

There are different interpretation methods, but in the frameworks of this study we will use two interpretation methods: computation of predictions for each observation in the sample and discrete change in the outcome variables at different values of the independent variables. In the case of computing predictions for each observation, the predicted value of a particular outcome for each case in the sample is calculated. Predicted probabilities for each observation show the range of predicted probabilities from the lowest to the highest as well as the average probability. As for the discrete change, it is possible to calculate predicted probabilities for a given change in a independent variable, but when it is important to remember that in this case we deal with hypothetical cases approximated to the available data (Long \& Freese, 2006). Also, it is important to be cautious when it making a decision about values at which other independent variables should be held constant. The choice of the values should be done in relation to the behavior of variables and the level of measurement of variables. For instance, when independent variables are skewed, choosing the median over the mean is more appropriate or when we have a binary variable it is more appropriate to choose the change from 0 to 1 . Prediction of values for substantively meaningful profiles or, in other words, "ideal types", is the method when several independent variables are held at some particular values, which comprise a type in 
which researcher is interested, as for instance, "the group of women who did not attend college and have no kids" (Long \& Freese, 2006).

\section{Findings}

According to the results of logit analysis, all control variables (gender, tangibility of the future offering, the length of contact with counsellors) predict discontinuation of venture ideas. When it comes to dimensions of entrepreneurial self-efficacy, planning ( $z=1,69$, $p<0,1)$ and marshalling $(z=-2,82, p<0,05)$ self-efficacy predict discontinuation of venture ideas. Searching, implementing people, and implementing finances self-efficacy do not predict the discontinuation of venture ideas. Therefore, we conclude that hypotheses $1,4,5$ are not supported.

The hypothesis 3 proposed that lower marshalling self-efficacy predicted discontinuation of venture ideas and the results of the logit test have proved it, so the hypothesis 3 is accepted. The proposition formulated in the hypothesis 2 said that lower planning selfefficacy predicted discontinuation of venture ideas, but the results of the logit test showed the opposite result - higher planning self-efficacy predicts discontinuation of venture ideas. Therefore, the hypothesis 2 is refuted.

Table 5. Results of logit analysis

\section{Control variables}

$\begin{array}{lll}\text { Gender } & 0,41 & * \\ \text { Product versus service } & 0,60 & * * \\ \text { The length of contact with counsellors } & -0,67 & \\ \text { Searching } & -0,19 & * \\ \text { Planning } & 0,24 & * \\ \text { Marshaling } & -0,36 & * * \\ \text { Implementing people } & 0,15 & \\ \text { Implementina finances } & -0,40 \\ \text { Pseudo R } & & \\ \text { LR chi2 } & 0,06 & \\ \mathrm{~N}=378 & 25,79\end{array}$

Notes: Standardized regression coefficients are displayed in the table.

The level of statistical significance: ${ }^{*}$ indicates $p<0,1 ;{ }^{* *}$ indicates $p<0,05 ;{ }^{* * *}$ indicates $p<0,01$ for two-tailed tests

As the control variable tangibility of the future offering predicted discontinuation of the venture ideas, we decided to look at how the change in specific self-efficacy influences the discontinuation of venture ideas based on products $(\mathrm{N}=251)$ and venture ideas based on services $(\mathrm{N}=156)$. Both Figures show that the probability of discontinuation is higher for entrepreneurs who had venture ideas based on products, but the differences between 
these two groups are insignificant $(95 \% \mathrm{Cl}: 0,01 ; 0,16$ (for planning self-efficacy=2) and 0,$03 ; 0,26$ (for planning self-efficacy $=7$ ); 0,$01 ; 0,26$ (for marshalling self-efficacy $=1$ ) and 0,01 ; 0,15 (for marshalling self-efficacy=7), except for the significant difference between these two groups when the planning self-efficacy is lowest (planning self-efficacy=1).

Figure 4. The predicted probability of discontinuation and planning entrepreneurial selfefficacy depending on the type of venture idea

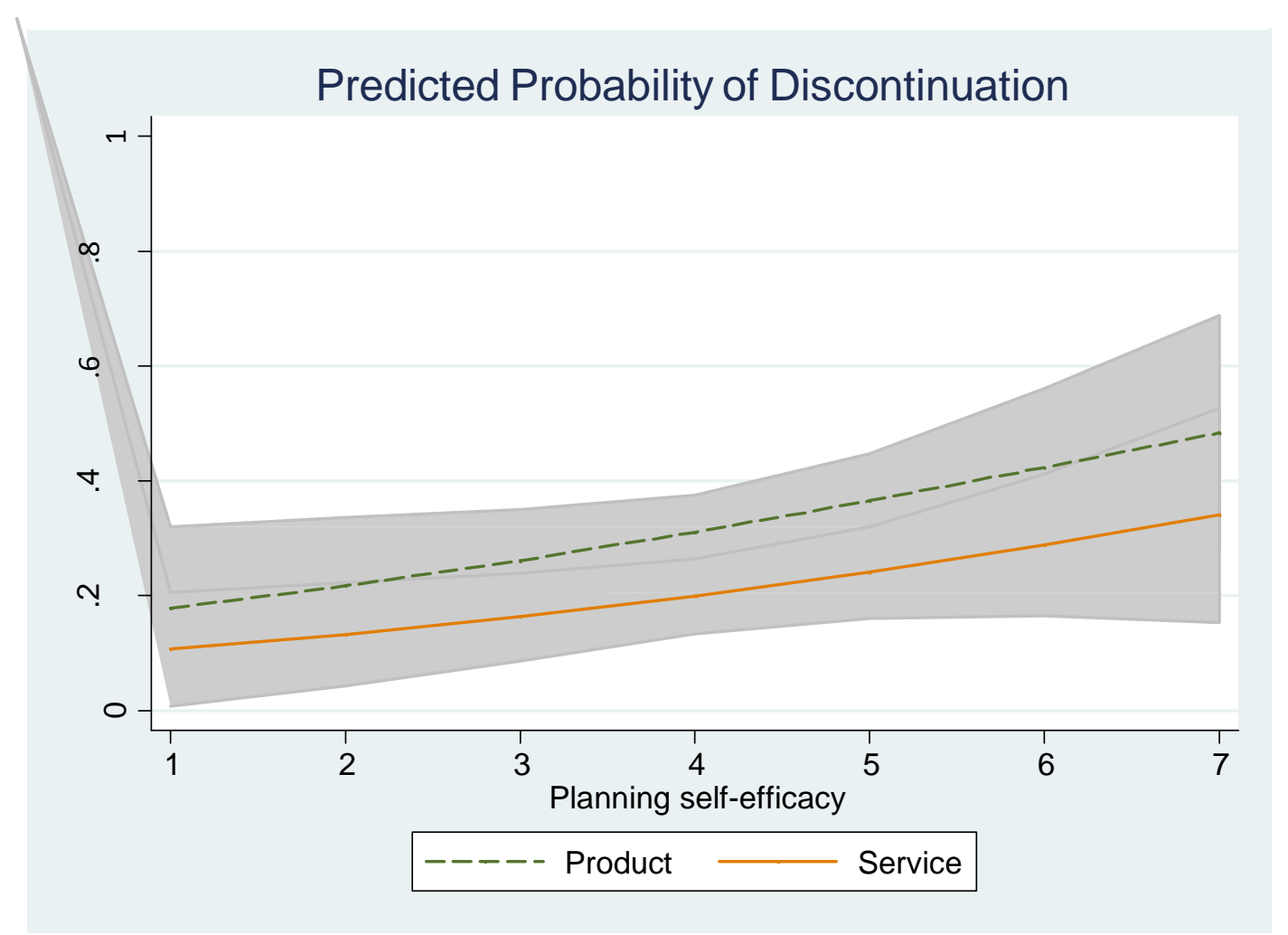


Figure 5. The predicted probability of discontinuation and marshaling entrepreneurial selfefficacy depending on the type of venture idea

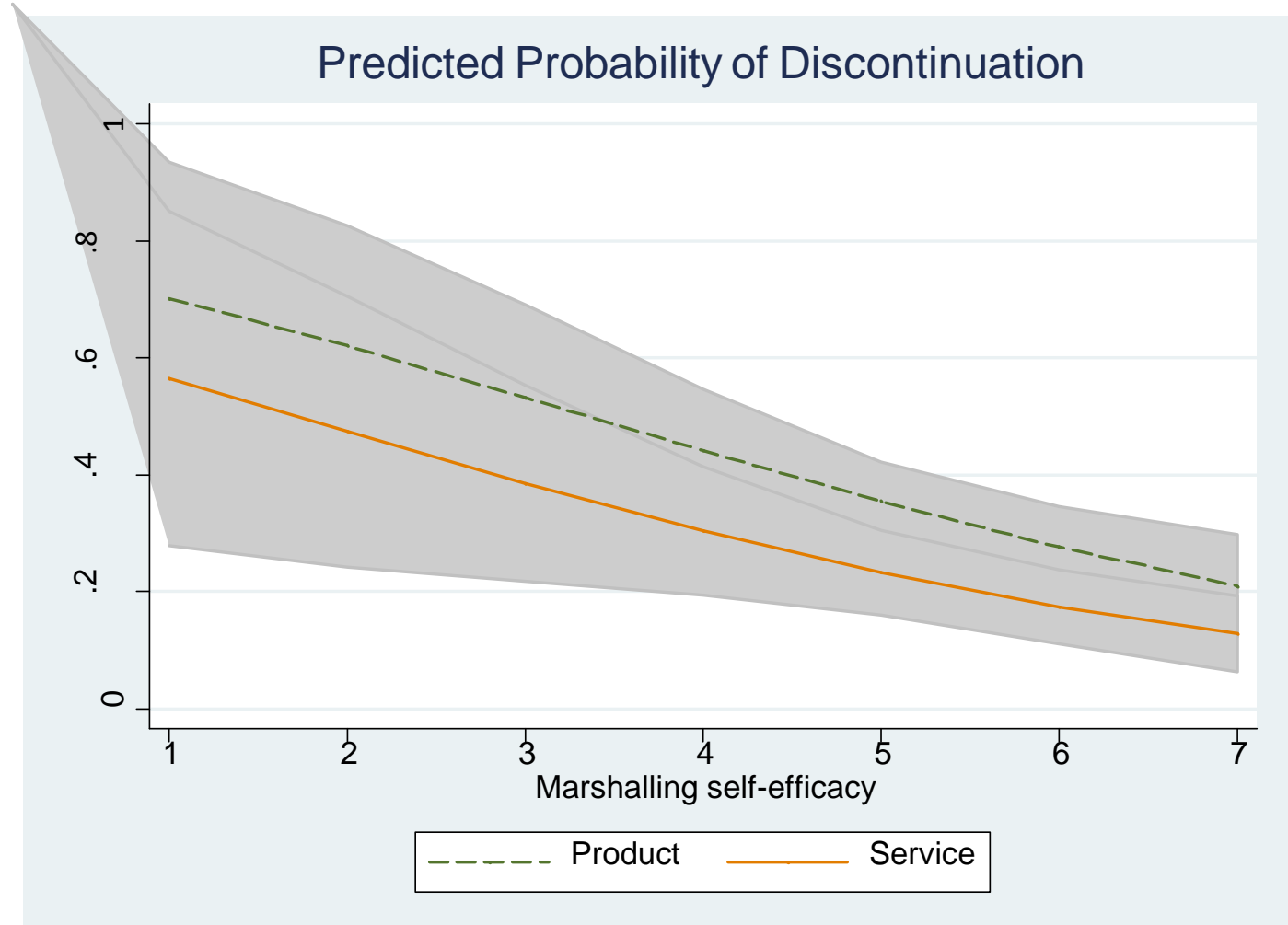

Although the differences between two groups are not significant, the Figures 4 and 5 show that there is qualitative change in the predicted probabilities of discontinuation depending on the change in entrepreneurial self-efficacy. So, for instance, when we look at the planning self-efficacy on Figure 4, we can see that the predicted probability of discontinuation of venture ideas increases as the planning self-efficacy increases. The Figure 5 shows that the predicted probability increases as the marshalling self-efficacy increases. 
Figure 6. The predicted probability of discontinuation and planning entrepreneurial selfefficacy depending on length of contact with counsellors

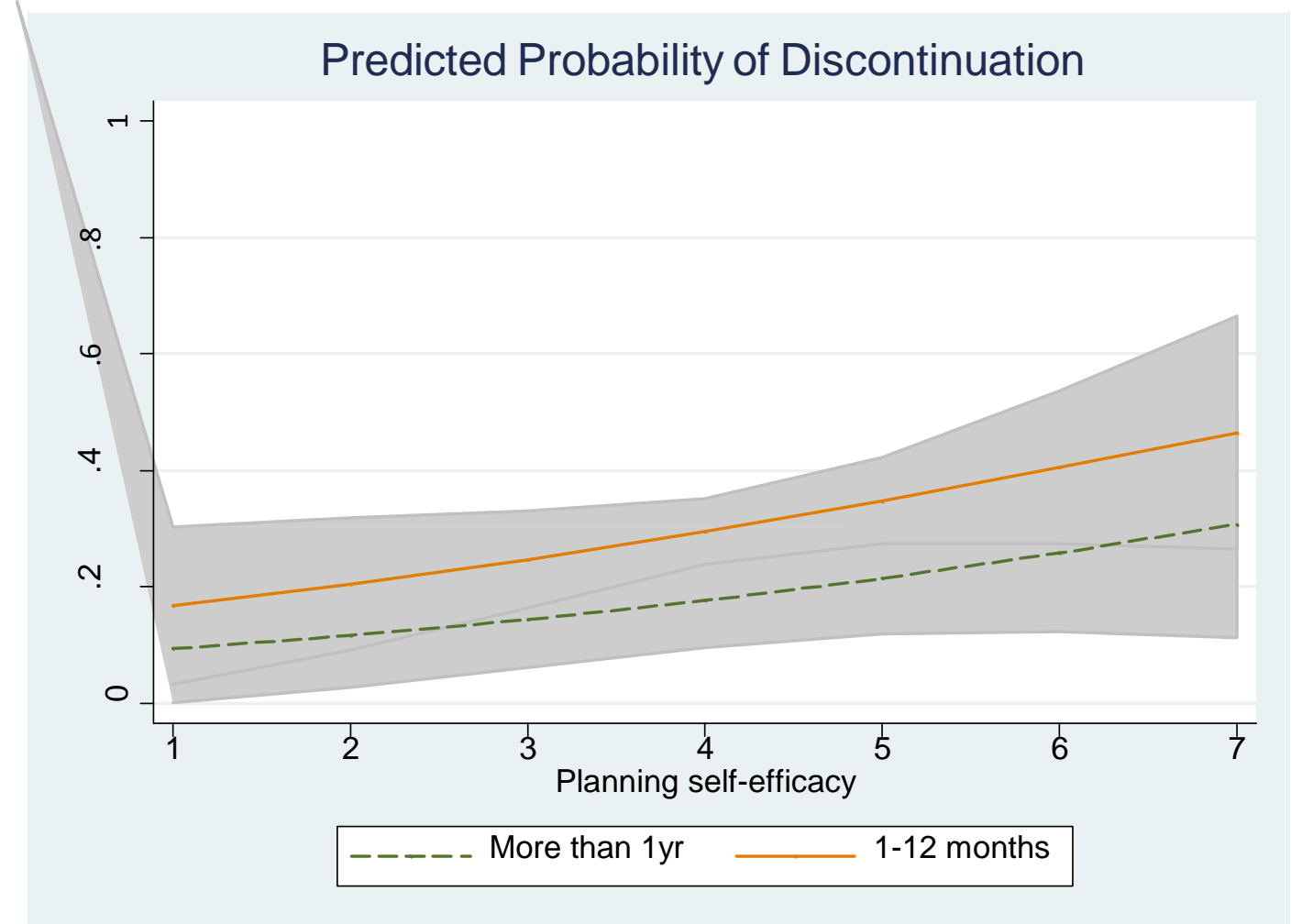

The control variable the legth of contact with counsellors was significant in the logit test. The Figure 6 shows that the predicted probability of discontinuation of venture ideas is higher among entrepreneurs who have received support from counsellors during one year in comparison with those who have been in contact with the support agency for longer than one year. However, there were no statistically significant differences between these two groups. As in previous figures, the predicted probability of discontinuation increases as planning self-efficacy increases.

When it comes to marshalling self-efficacy, the results are similar: entrepreneurs who have been in contact only for one year tend to abandon or delay exploitation of their venture ideas (see Figure 7). Again, the predicted probability of discontinuation decreases as marshalling self-efficacy increases. As in the previous Figure 6, the differences between two groups of entrepreneurs are not significant. 
Figure 7. The predicted probability of discontinuation and marshalling entrepreneurial selfefficacy depending on length of contact with counsellors

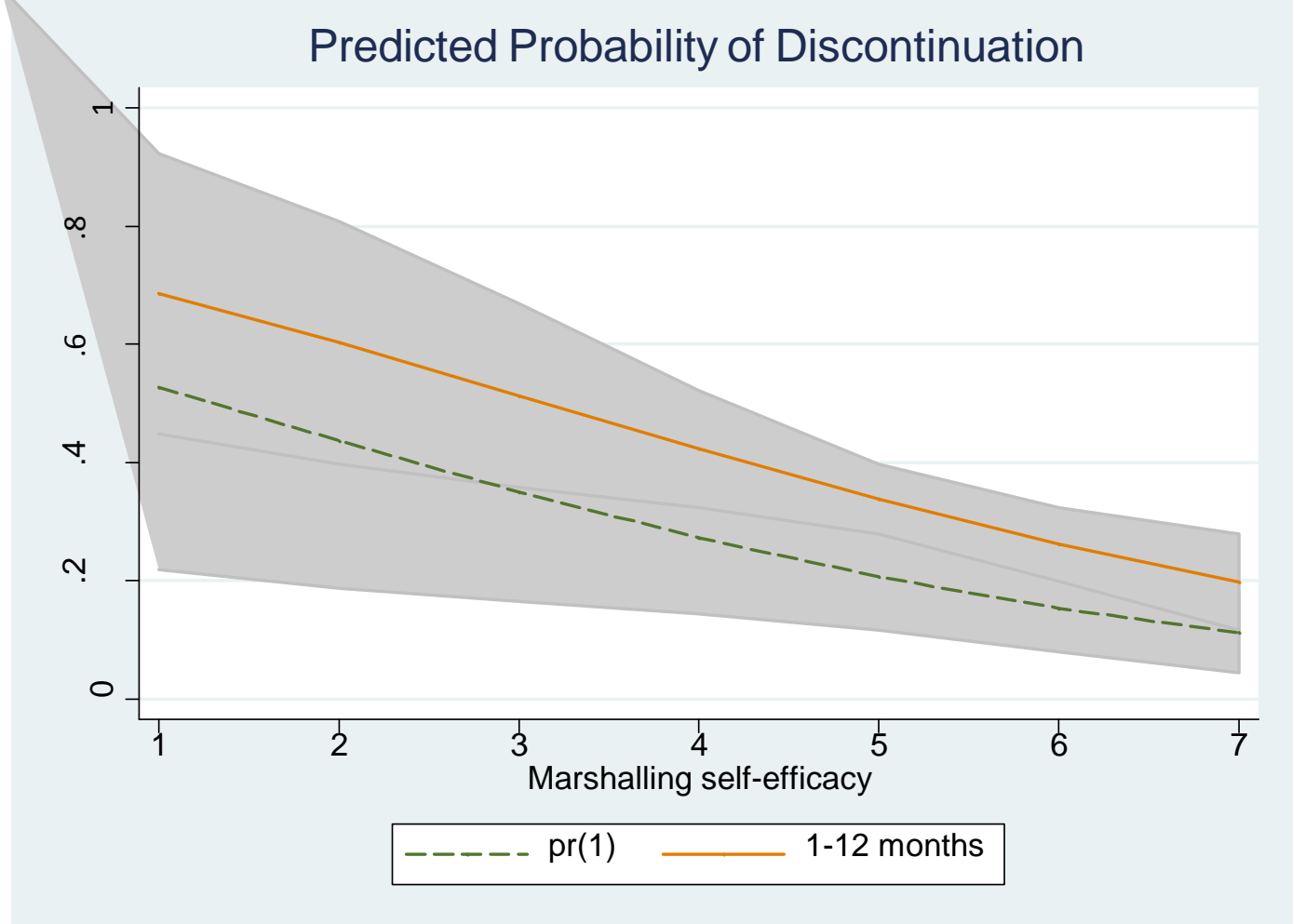

\section{Discussion}

The study showed that the length of contact, tangibility of future offerings, and two dimensions of entrepreneurial self-efficacy predict discontinuation of venture ideas. The study demonstrated that among five dimensions of entrepreneurial self-efficacy, planning and marshalling self-efficacy predict discontinuation of venture ideas of entrepreneurs who have received support of counsellors. Planning and marshalling self-efficacy have similar effects on the discontinuation of venture ideas irrespective of the type of the future offering, i.e., although entrepreneurs with venture ideas based on services have lower probability of discontinuation (difference is not significant), the direction of the relationship of planning and marshalling self-efficacy and discontinuation is similar. For both groups in the case of planning self-efficacy, as planning self- efficacy increases, the probability of discontinuations increases, too. When it comes to marshalling self-efficacy, the probability of discontinuation increases as marshalling self-efficacy decreases.

As for the second part of the research question concerning the difference between venture ideas based on products versus venture ideas based on services, we have not found any statistical differences between these two groups in entrepreneurial self-efficacy. However, the figures of predicted probabilities showed some qualitative differences between these two groups. Entrepreneurs developing future services seem to have lower predicted probability of discontinuation of their venture ideas. The same conclusion can be 
made about the influence of length of contact. There were no statistically significant differences between the group of those who were in contact with counsellors for one year and those who were in contact for longer in entrepreneurial self-efficacy, but the first group generally seems to have higher predicted probability of discontinuation.

According to the results, higher planning self-efficacy predicts discontinuation of venture ideas. This might be an indication that entrepreneurs who are prone to excessive planning during early stages of the entrepreneurial process are more likely to fail or abandon their venture ideas. Analysis shows that discontinuation is predicted by low marshalling self-efficacy. Therefore, it can be recommended that entrepreneurs during the discovery stage are better off if they improve their marshaling self-efficacy and allow themselves more flexibility rather than constrict themselves in stringent planning.

In conclusion, entrepreneurs developing services tend to be better off in comparison with their colleagues developing products, but there were not significant differences in planning and marshalling self-efficacy between these two groups. The explanation can be that entrepreneurial self-efficacy and tangibility of future offerings are not enough in explaining discontinuation of venture ideas. As we do not possess enough evidence to suggest that entrepreneurs need to have different sets of abilities depending on the tangibility of future offerings, it can be advised that future research should focus on studying the differences between new product and new service development processes among nascent entrepreneurs and focus on development of entrepreneurial self-efficacy along this process. 


\section{Appendix}

Table 6. Means and standard deviations for items of perceived entrepreneurial self-efficacy scale

\begin{tabular}{|c|c|c|c|c|c|}
\hline \multirow[t]{5}{*}{ Var name } & \multirow{3}{*}{\begin{tabular}{|l} 
Searching self-efficacy (alpha $=0.73$ ) \\
Brainstorm a new idea for a product or service
\end{tabular}} & \multicolumn{2}{|c|}{ Obs|MeanStd. } & \multicolumn{2}{|c|}{ Min Max } \\
\hline & & & Dev. & & \\
\hline & & & & & \\
\hline & Identify the need for a new product or service & & & & \\
\hline & $\begin{array}{l}\text { Design a product or service that will satisfy customer } \\
\text { needs and wants }\end{array}$ & & & & \\
\hline \multirow[t]{5}{*}{ Var name } & Planning self-efficacy (alpha $=0.81$ ) & & $\begin{array}{l}\text { Std. } \\
\text { Dev. }\end{array}$ & & \\
\hline & Estimate customer demand for a new product or & & & & \\
\hline & Determine a competitive price for a new product or & & & & \\
\hline & $\begin{array}{l}\text { Estimate the amount of start-up funds and working } \\
\text { capital necessary to start my business }\end{array}$ & & & & \\
\hline & $\begin{array}{l}\text { Design an effective marketing/advertising campaign } \\
\text { for a new product or service }\end{array}$ & & & & \\
\hline \multirow[t]{4}{*}{ Var name } & Marshaling resources self- efficacy (alpha $=0.76)$ & & Std. & & \\
\hline & $\begin{array}{l}\text { Get others to identify with and believe in my vision } \\
\text { and plans for a new business }\end{array}$ & & & & \\
\hline & $\begin{array}{l}\text { Network - i.e., make contact with and exchange } \\
\text { information with others }\end{array}$ & & & & \\
\hline & $\begin{array}{l}\text { Clearly and concisely explain verbally/in writing my } \\
\text { business idea in everyday terms }\end{array}$ & & & & \\
\hline Var name & Implementing people self- efficacy (alpha $=0.93)$ & & Std. & & \\
\hline implemp1 & Supervise employees & 3934,98 & 1,72 & 1 & 7 \\
\hline \multirow[t]{4}{*}{ implemp2 } & Recruit and hire employees & 3924,60 & 1,87 & 1 & 7 \\
\hline & Delegate tasks and responsibilities to employees & & & & \\
\hline & Deal effectively with day-to-day problems and crises & & & & \\
\hline & Inspire, encourage and motivate my employees & & & & \\
\hline implemp6 & Train employees & 3835,37 & 1,57 & 1 & 7 \\
\hline Var name & Implementing finances self- efficacy (alpha $=0.87)$ & & $\begin{array}{l}\text { Std. } \\
\text { novy }\end{array}$ & & \\
\hline implemfin 1 & Organize and maintain the financial records of my & & & & \\
\hline \multirow{2}{*}{\begin{tabular}{|l|} 
implemfin 2 \\
implemfin 3
\end{tabular}} & 2 Manage the financial assets of my business & & & & \\
\hline & Read and interpret financial stat & & & & \\
\hline
\end{tabular}




\section{References}

Aldrich, H. (1999). Organizations evolving London, UK: Sage Publications.

Alvarez, S., \& Busenitz, L. (2001). The entrepreneurship of resource-based theory. Journal of Management, 755-775.

Amason, A., C., Shrader, R., C., \& Tompson, G., H. (2006). Newness and novelty: Relating top management team composition to new venture performance. Journal of Business Venturing, 21(1), 125-148.

Ardichvili, A., Cardozo, R., \& Ray, S. (2003). A theory of entrepreneurial opportunity identification and development. Journal of Business Venturing, 18, 105-123.

Bandura, A. (1977). Social Learning Theory. New York: General Learning Press. Bandura, A. (1997). Self-efficacy : the exercise of control. New York: W.H. Freeman.

Bandura, A. (2006). Guide for constructing self-efficacy scales. Greenwich: Information Age Publishing.

Becker, G. S. (1993). Human capital: A theoretical and empirical analysis with special reference to education (3rd ed.). Chicago: University of Chicago Press.

Bird, B. (1988). Implementing Entrepreneurial Ideas: The Case for Intention. The Academy of Management Review, 13.

Busenitz, L., West, G. P., Shepherd, D., Nelson, T., Chandler, G., \& Zacharakis, A. (2003). Entrepreneurship research in emergence: past trends and future directions. Journal of Management, 29(3), 285-308.

Carlsson, B. (2005). Entrepreneurship and Public Policy in Emerging Clusters.Unpublished manuscript, Cleveland, Ohio.

Castrogiovanni, G. J. (1996). Pre-startup planning and the survival of new small businesses: Theoretical linkages. Journal of Management, 22(6), 801-822.

Chen, G. C., Greene, P. G., \& Crick, A. (1998). Does entrepreneurial self-efficacy distinguish entrepreneurs from managers? . Journal of Business Venturing, 13(4), 295-316.

Chen, G. C., Gully, M. S., \& Eden, D. (2004). General self-efficacy and self-esteem: Toward theoretical and empirical distinction between correlated self-evaluations. Journal of Organizational Behavior, 25, 375-395.

Choi, Y. R., \& Shepherd, D. A. (2004). Entrepreneurs' Decisions to Exploit Opportunities. Journal of Management, 30(3), 377-395.

Chrisman, J., \& McMullan, E. (2004). Outsider Assistance as a Knowledge Resource for New Venture Survival. Journal of Small Business Management, 42(3), 229-244. 
The CER working Paper Series on Entrepreneurship and Innovation

Christman, J., J., McMullan, E., \& Hall, J. (2005). The influence of guided preparation on the long- term performance of new ventures. Journal of Business Venturing, 20(6), 769819 .

Cooper, A., \& Mehta, S. (2006). Preparation for Entrepreneurship: Does it Matter? The Journal of Private Equity, 9(4), 6-15.

Davidsson, P. (2004). Researching Entrepreneurship: Springer.

Davidsson, P. (2006). Nascent entrepreneurship: empirical studies and developments.

Foundations and Trends in Entrepreneurship, 2(1), 1-76.

Davidsson, P. (2008). The entrepreneurship research challenge. Cheltenham: Edward Elgar.

Davidsson, P., \& Honig, B. (2003). The role of social and human capital among nascent entrepreneurs. Journal of Business Venturing, 18(3), 301-331.

Delmar, F., Davidsson, P., \& Gartner, W. B. (2003). Arriving at the high-growth firm. Journal of Business Venturing, 18(2), 189-216.

Delmar, F., \& Shane, S. (2003). Does business planning facilitate the development of new ventures? . Strategic management journal, 24, 1165-1185.

Devece, C. A., Palacios-Marques, D., \& Fernandez, R. (2011). Entrepreneurship research in service industries: a literature classification and trend analysis. International Entrepreneurship and Management Journal, 7.

Dimov, D. (2010). Nascent Entrepreneurs and Venture Emergence: Opportunity Confidence, Human Capital, and Early Planning. Journal of Management Studies, 47(9).

Dobrev, S. D., \& Barnett, W. P. (2005). Organizational roles and transition to entrepreneurship.

Academy of Management Journal, 48(3), 433-449.

Drnovsěk, M., Wincent, J., \& Cardon, M. (2010). Entrepreneurial self-efficacy and business start- up: developing a multi-dimensional definition. International Journal of Entrepreneurial Behaviour \& Research, 16(4), 329-348.

Edvardsson, B., Olsson, J. (1996). Key Concepts for New Service Development. The Service Industries Journal, 16 (2), 140-164.

Fiet, J. (2007). A Prescriptive Analysis of Search and Discovery. Journal of Management Studies, 44(4).

Hair, J., Black, W., Babin, B., Anderson, R., \& Tatham, R. (2006). Multivariate Data Analysis. 
The CER working Paper Series on Entrepreneurship and Innovation

Upper Saddle River, NJ: Pearson/Prentice Hall.

Hechavarria, D. M., Renko, M., \& Matthews, C. H. (2011). The nascent entrepreneurship hub: goals, entrepreneurial self-efficacy and start-up outcomes. Small Business Economics.

Ireland, R. D., \& Webb, W. J. (2007). A Cross-Disciplinary Exploration of Entrepreneurship Research. Journal of Management, 33.

Isaksen, E. J. (2006). Early Business Performance - Initial factors effecting new business outcomes Bodo Graduate School of Business Bodo.

Klofsten, M. (2005). New venture ideas: an analysis of their origin and early development.

Technology Analysis \& Strategic Management, 17(1), 105-119.

Kogut, B., \& Zander, U. (1992). Knowledge of the Firm, Combinative Capabilities, and the Replication of Technology. Organization Science, 3(3), 383-397.

Krueger, N. (1993). The impact of prior entrepreneurial exposure on perceptions. Entrepreneurship Theory and Practice, 18(1), 5-22.

Krueger, N. (2000). The Cognitive Infrastructure of Opportunity Emergence. Entrepreneurhip Theory and Practice.

Long, S., \& Freese, J. (2006). Regression Models for Categorical Dependent Variables Using Stata. USA: College Station.

McGee, J., Peterson, M., Mueller, S., \& Sequeira, J. (2009). Entrepreneurial Self-Efficacy: Refining the Measure. Entrepreneurhip Theory and Practice.

Medina, T. (2011). Categorical Data Analysis: Models for Binary, Ordinal, Nominal, and Count Outcomes. Unpublished Course Compendium. ICPSR Summer Program

Mueller, S., \& Conway Dato-On, M. (2008). Gender-role orientation as a determinant of entrepreneurial self-efficacy. Journal of Developmental Entrepreneurship, 13(1), 3-20.

Mueller, S., \& McGee, J. (2007). The influence of social ties and self-efficacy in forming entrepreneurial intentions and motivating nascent behavior. Journal of Developmental Entrepreneurship, 12(3), 275-293.

Ordanini, A., \& Parasuraman, A. (2011). Service Innovation Viewed Through a ServiceDominant Logic Lens: A Conceptual Framework and Empirical Analysis. Journal of Service Research, 14(3).

Powers, D., \& Xie, Y. (2008). Statistical Methods for Categorical Data Analysis. Bingley, UK: Emerald Group Publishing Limited.

Puhakka, V. (2007). Effects of Opportunity Discovery Strategies of Entrepreneurs on Performance of New Ventures. The Journal of Entrepreneurship, 16(1), 19-19. 
The CER working Paper Series on Entrepreneurship and Innovation

Rotefoss, B., \& Kolvereid, L. (2005). Aspiring, nascent and fledgling entrepreneurs: an investigation of the business start-up process. Entrepreneurship and Regional Development, 17(2).

Samuelsson, M. (2004). Creating New Ventures: A longitudinal Investigation of the nascent venturing process. Jönköping International Business School, Jönköping.

Sarasvathy, S., Dew, N., Velamuri, R., \& Venkataraman, S. (2005). Three Views of Entrepreneurial Opportunity. In Z. Acs \& D. Audretsch (Eds.), Handbook of Entrepreneurship Research. Dordrecht: Kluwer Academic Publishers.

Shane, S., \& Venkataraman, S. (2000). The promise of entrepreneurship as a field of research.

Academy of Management 25(1), 217-226.

Song, L., Song, M., Benedetto, A., D. (2009). A Staged Service Innovation Model. Decision sciences, 40(3), 571-599.

Ucbasaran, D., Westhead, P., \& Wright, M. (2008). Opportunity Identification and Pursuit: Does an Entrepreneur's Human Capital Matter? Small Business Economics, 30, 153-173.

Ucbasaran, D., Westhead, P., \& Wright, M. (2009). The extent and nature of opportunity identification by experienced entrepreneurs. Journal of Business Venturing, 24, 99-115.

Unger, J. M., Rausch, A., Frese, M., \& Rosenbusch, N. (2011). Human capital and entrepreneurial success: A meta-analytical review. Journal of Business Venturing, 26.

van Gelderen, M., Thurik, R., \& Bosma, N. (2006). Success and Risk Factors in the PreStartup Phase. Small Business Economics, 26(4), 319-335.

Wiklund, J. (1998). Small Firm Growth and Performance: Entrepreneurship and Beyond. Jonkoping International Business School. , Jönköping.

Wilson, F., Kickul, J., \& Marlino, D. (2007). Gender, Entrepreneurial Self-Efficacy, and Entrepreneurial Career Intentions: Implications for Entrepreneurship Education1. Entrepreneurship Theory and Practice, 31(3), 387-406. 